\title{
Zagonetka nebića i Aristotelova subjektno-predikatna analiza
}

\author{
Igor Martinjak*
}

\begin{abstract}
Sažetak
U ovom radu argumentiram da se prihvaćajući tradicionalnu koncepciju egzistencije i predikacije ne obvezujemo na zloglasni paradoks nebića. Negativne egzistencijalne rečenice jednostavno nisu subjektno-predikatne rečenice kojima se izdvajaju neka bića da bismo o njima rekli da ne postoje. Aristotelovo insistiranje da biće nije rod, tj. da biće nije predikat nekoga subjekta ključno je za takvu tvrdnju. Ipak, unutar konceptualnoga okvira Aristotelove filozofije izvire drugačiji problem nebića. Rekonstruiram Aristotelovo rješenje kao zadovoljavajuće s obzirom na njegovo razumijevanje predikacije i egzistencije. Štoviše, sugeriram kako slična zagonetka vodi mnoge suvremene filozofe prema napuštanju quineovske koncepcije egzistencije i predikacije u korist tradicionalnijih pristupa.
\end{abstract}

Ključne riječi: egzistencija; nebiće; predikacija; načini postojanja

\section{Uvod}

»Poopćeni, metafizički pojam egzistencije, razdvojen od predikacije — kao što je glagol egzistira razdvojen od predikativne konstrukcije - u opasnosti je od slobodnoga plutanja bez ikakva fiksnoga semantičkoga okvira referencije, a time i bez jasnoga značenja « (Kahn, 2009, 142). ${ }^{1}$ To su posljednje riječi Kahnova poznata teksta $A$ Return to the Theory of the Verb Be and the Concept of Being, ali i zaključak Kahnova četrdesetgodišnjega istraživanja uporabe i značenja glagola biti u antičkoj filozofiji. Naime, koncepcija bića - ili čak bitka - u antičkoj filozofiji u svim je aspektima suprotna od stavaka koje bismo mogli izlučiti iz citiranoga odlomka. Glagol biti u antičkoj filozofiji, a posebice kod Aristotela, u primarnom je smislu korišten predikativno u tzv. tročlanim subjektno-predikatnim rečenicama forme "S je P". Nadalje, svaka afirmativna subjektno-predikatna re-

\footnotetext{
* Dr. sc. Igor Martinjak, Fakultet filozofije i religijskih znanosti Sveučilišta u Zagrebu. Adresa: Jordanovac 110, 10000 Zagreb, Hrvatska. ORCID iD: https://orcid.org/0000-0002-2726-4036. E-adresa: igor.martinjak@yahoo.com

1 Sve je citate na hrvatski jezik preveo autor rada.
} 
čenica, moderno rečeno, implicira egzistenciju stvari koja odgovara subjektnomu terminu. Takvima se tročlanim subjektno-predikatnim rečenicama jednostavno objelodanjuje da određeni odsječak izvanmentalne i izvanjezične zbilje jest. Međutim, ako je tako, onda bismo tipične egzistencijalne rečenice forme "S jest" ( $\mathrm{tj}$. postoji ili egzistira) trebali shvatiti kao eliptične rečenice koje zahtijevaju dopunu nekim predikatnim imenom. Reći da nešto jest (tj. postoji ili egzistira) pretpostavlja tvrdnju da nešto jest nešto.

Citirani odlomak također ukazuje na Kahnovo nepovjerenje prema suvremenomu shvaćanju egzistencije. Riječ je, dakako, o onoj koncepciji egzistencije i predikacije koju nalazimo u radovima Fregea, Russella i Quinea. Najveći izazov takvoj koncepciji predstavlja fikcijski diskurs. Naime, za spomenuta tri filozofa egzistencija nije svojstvo pojedinačnosti označenih singularnim terminima, nego svojstvo pojmova izraženih generalnim terminima. Sukladno tomu, kada tvrdimo "Mačka postoji", tvrdimo da ima barem jedna instancija pojma izraženoga generalnim izrazom mačka. Rečenicom pak "Himera ne postoji" izražavamo da je broj instancija pojma izraženog izrazom Himera jednak nuli. Međutim, ako je tako, onda su singularne egzistencijalne tvrdnje besmislene ili u najboljem slučaju neinformativne tautologije lišene sadržaja s obzirom na to da singularni termini po definiciji označavaju postojeće predmete koji mogu biti instancije pojmova (usp. Frege, 1960; Russell, 2010, 64-69; Quine, 2011, 73-90). Problem fikcijskoga diskursa za skiciranu teoriju egzistencije i predikacije počiva upravo na činjenici da ne možemo konzistentno tvrditi da su Pegaz i Sherlock Holmes nepostojeće stvari i da su rečenice "Pegaz je bijel" i "S. Holmes je detektiv" istinite. Naime, pojmovi izraženi s bijel i detektiv mogu biti jedino instancirani u postojećim stvarima, ali samim time spomenute rečenice obvezuju da izrazi Pegaz i S. Holmes imenuju postojeće stvari (usp. Crane, 2011, 427-430).

S druge strane, troje gore spomenutih filozofa uvjerava nas da tradicionalna koncepcija egzistencije vodi prema paradoksu nepostojećega, odnosno prema problemu Platonove brade (usp. Quine, 1980, 1-3). Naime, ako se i egzistencijalne rečenice trebaju analizirati kao subjektno-predikatne rečenice, onda smo negiranjem egzistencije obvezani na tvrdnju da postoji nešto što ne postoji. Primjerice, rečenica "Lastavica nije sisavac", kako se vjeruje, prema subjektno-predikatnoj analizi obvezuje nas da predmeti izdvojeni subjektnim terminom nemaju svojstvo izraženo predikatnim terminom, ali ako na isti način analiziramo rečenicu "Himera ne postoji", obvezani smo na to da postoje predmeti izdvojeni subjektnim terminom koji ne postoje. Ali ako egzistenciju shvatimo kao svojstvo pojmova, negativne se egzistencijalne rečenice lako razrješavaju kao tvrdnje da je broj instancija nekoga pojma jednak nuli.

U ovom radu pokazujem sljedeće: (a) da je Aristotelova subjektno-predikatna analiza imuna na paradoks nepostojećega; (b) da Aristotel uspješno rješava njemu relevantne nedoumice o nepostojećem; (c) sugeriram kako se mnoga suvremena rješenja problema fikcijskoga diskursa osnivaju na napuštanje quineovskoga shvaćanja egzistencije te implicitno ili eksplicitno vode prema tradicionalnijim pristupima. 


\section{Izraz biće kao predikatno ime}

Što se tiče paradoksa nepostojećega, dovoljno je pokazati da Aristotel rečenicu "Himera ne postoji" nikada ne bi shvatio kao subjektno-predikatnu rečenicu. Izraze poput postoji, biće i postojeće Aristotel ne shvaća kao izraze koji označavaju ono što se predicira. Iza izraza "ono što se predicira" skrivaju se upravo generalni termini koji označavaju univerzalije, za koje Aristotel tvrdi da se u primarnom smislu prediciraju (usp. Aristotel, 1974; De int. 7, 17a38-17b1; Aristotel, 1949; Apr. I. 27, 43a25-29). Tom tvrdnjom Aristotel upravo naglašava da je riječ o entitetima koji su zajednički za više pojedinačnosti. Dakako, mi bismo danas u takvom kontekstu rabili izraz instancirati ili oprimjeriti, a predicirati bismo čuvali za jezične entitete, točnije, generalne termine (usp. Loux, 2009, 189-190). U svakom slučaju, Aristotel želi, relativno blisko Fregeu, Russellu i Quineu, tvrditi da izrazi biće, postojeće i sl. ne izražavaju svojstva pojedinačnih predmeta. Na kraju krajeva, Aristotel primjećuje da je isto reći "x je čovjek" i "x je postojeći čovjek" (Aristotel, 1924a; Met. IV. 1003b27-30). U pozadini takvoga učenja nalaze se dvije poznate tvrdnje: "biće nije rod" i "biće se iskazuje na mnogo načina".

\subsection{Biće nije rod}

Argument za tvrdnju da biće nije rod pronalazimo u trećoj knjizi Metafizike.

»Nije moguće ni da je biće ni da je jedno rod. Nužno je, naime, da je svaka pojedina razlika svakoga pojedinoga roda i biće i jedno, ali nije moguće [...] da se rod predicira bez svojih vrsta. Prema tome, kad bi biće i jedno bili rod, nijedna razlika ne bi bila ni jedno ni biće« (Aristotel, 1924a; Met. B.3, 998b22-26).

Izrazi rod, vrsta i razlika standardni su izrazi iz Aristotelovih Kategorija, a posebice iz Topike (usp. Aristotel, 1974; Cat. 3, 1b17-23; 5, 3a22-26; 1963; Top. I.5, 101b38-102b27 i I.8, 103b1-19). Navedene izraze najjednostavnije možemo shvatiti kao klasifikacijske termine. Ne škodi naglasiti da za Aristotela ti klasifikacijski termini nisu rezultat primjene nekoga specifičnoga jezika ili specifične konceptualne sheme, nego se ti izrazi odnose na stvari u svijetu. Naime, ti izrazi funkcioniraju kao klasifikacijski termini i odnose se na univerzalije koje stoje u nekom odnosu prema drugim univerzalijama, odnosno njihovima instancijama. Rečenica "Sokrat je čovjek" istinita je rečenica zato što je, suvremeno rečeno, Sokrat instancija prirodne vrste čovjek, odnosno aristotelovski rečeno, zato što se vrsta čovjek predicira Sokratu. Kako mi znamo da je Sokrat primjerak neke vrste, a neko drugo biće, primjerice Palomita i Zvonko, neke druge vrste? Navedeno pitanje vodi nas prema tvrdnji da vrste nisu primitivne ili neanalizabilne univerzalije. Tradicionalna definicija iz Kategorija i Topike, koja podrazumijeva navođenje vrstotvorne razlike i najbližega roda, može se shvatiti upravo kao analiza takvih univerzalija. Primjerice, rečenice "Čovjek je racionalno živo biće", "Lastavica je F-asto živo biće" i "Mačka je G-asto živo biće” govore nam nešto o univerzalijama čovjek, lastavica i mačka. Prema tome, za Sokrata možemo reći da je čovjek zato što se o njemu prediciraju stvari u pozadini izraza racionalan $\mathrm{i}$ živo biće, za Palomitu kažemo da je lastavica zato što se o njoj prediciraju stvari 
u pozadini $F$ i živo biće, a za Zvonka pak možemo reći da je mačka zato što se o njemu prediciraju stvari u pozadini $G$ i živo biće. Primijetimo da se klasifikacija pojedinačnosti unutar neke vrste, vrste unutar roda, nižega roda unutar višega roda i dr. uvijek odvija unutar neke subjektno-predikatne strukture.

Razumijevanje Aristotelova argumenta da biće nije rod proizlazi upravo iz toga konteksta. Aristotel nam hoće reći da izrazom biće ne označavamo neki najviši rod koji je zajednički svim postojećim stvarima koje pripadaju u razne vrste i razne niže rodove. U tzv. Porfirijevu stablu — hijerarhijskoj strukturi postojećih stvari — koje možemo izgraditi klasificirajući sve pojedinačne stvari u vrste, vrste u rodove, niže rodove u više i dr., ne bismo smjeli u konačnici doći do najvišega roda koji nazivamo biće i koji bismo mogli predicirati o svemu, ali ništa drugo o njemu. Zašto bi tako nešto bilo sporno? Aristotelov argument, kako je vidljivo iz citiranoga odlomka, počiva na dvije tvrdnje: (a) »Nužno je, naime, da je svaka pojedina razlika svakoga pojedinoga roda biće « (Aristotel, 1924a; Met. B.3, 998a23-24) i (b) »nije moguće da se rod predicira prema razlikama bez svojih vrsta (Aristotel, 1924a; Met. B3, 998a24-26). Prva tvrdnja je intuitivna i jasna na osnovi rečenoga. Aristotel jednostavno dodatno naglašava da obilježje u pozadini izraza racionalan nije neko fikcijsko obilježje koje ne može biti eksplanatorni faktor nijedne činjenice o izvanmentalnoj stvarnosti. Kod Aristotela objašnjenje različitoga ponašanja ljudi i mačaka počiva upravo na tom da postoji neko obilježje koje pripada ljudima, a ne mačkama. Sposobnost čitanja i računanja kod ljudi, primjerice, počiva upravo na racionalnosti koja se predicira ljudima, a mačkama ne.

Aristotelova druga tvrdnja puno je kompliciranija. Nama je dovoljno zastati nad misli da se rod ne može predicirati razlici. U našem slučaju rod izražen sa živo biće ne možemo predicirati razlici izraženoj s racionalan. Zašto bi takvo nešto bilo sporno? Pa ako se dvije vrste unutar istoga roda živih bića razlikuju na osnovi razlike izražene s racionalan o kojoj se može istinito predicirati rod izražen sa živo biće, onda se dvije vrste razlikuju unutar istoga roda na osnovi toga istoga roda. Ili, još apsurdnije, ako važi predikacija "Čovjek je racionalno živo biće” i predikacija "Racionalan je živo biće", onda važi i "Čovjek je živo biće živo biće". ${ }^{2}$ Razlika dviju vrsta unutar istoga roda ne može biti nešto o čemu se unutar subjektno-predikatne strukture predicira taj rod neovisno o samoj vrsti. Rod se, naime, kao i razlika, predicira vrsti i njezinim pojedinačnim instancijama, ali nije moguće predicirati rod o razlici uzimajući razliku kao nešto odvojeno od same vrste.

Sada možemo rekonstruirati Aristotelov reductio argument za tvrdnju da biće nije rod.

(1) Biće je rod (tj. biće se predicira)

pretpostavka za reductio

(2) Rod se ne predicira o razlici F prema stavku (b)

(3) Razlika F nije biće

(4) Razlika F je biće

iz (2) i (1)

(5) Dakle, biće nije rod prema stavku (a) reductio ad absurdum 
Usputni stavak (4'): rečenica “Razlika (npr. F) je biće” nije predikacija.

Koliko je Aristotelov argument uspješan i je li takva rekonstrukcija adekvatna pitanje je spora (usp. Berti, 2009, 121-126), ali Aristotel na drugim mjestima ukazuje na to zašto biće nije rod i što uopće stoji u pozadini izraza biće.

\subsection{Biće se iskazuje na mnogo načina}

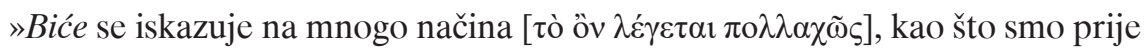
razlučili u raspravama o tomu na koliko se načina za nešto kaže da jest. Naime, s jedne strane 'biće' označava ono što jest ili neko ovo, a s druge ono koliko jest ili ono kakvo jest ili sve pojedino od toga što se tako predicira nečemu. Premda se na toliko načina biće iskazuje, evidentno je da je od tih primarno 'ono što jest', tj. ono što označava supstanciju [...] a za sve ostalo kažemo da je biće zato što je kvantiteta, kvaliteta, stanje i što god drugo supstancije« (Aristotel, 1924b; Met. Z.1, 1028a103-20).

Osnovna je misao u navedenom odlomku, kao i u njemu sličnima (usp. Aristotel, 1924a; Met. IV.2; 1003a33-b10 i V.7, 1017a22-27), ta da je izraz biće na neki način višeznačan. Za Fregea, Russella i Quinea biće (postojeće ili egzistirajuće) i bivanje (postojanje ili egzistencija) i te kako su jednoznačni izrazi. Bića su jednostavno pojedinačni predmeti koji se mogu pojaviti kao instancije nekih pojmova, a bivanje je jednostavno ono što je izraženo egzistencijalnim kvantifikatorom - takvo svojstvo pojma na osnovi kojega znamo da postoji barem jedna njegova instancija (usp. Inwagen, 2009).

Aristotel, međutim, tu ne misli na polisemiju, nego na neku vrstu homonimije koja je u Kategorijama shvaćena kao obilježje stvari, a ne riječi (Aristotel, 1974; Cat. 1, 1a1-6). Prema tomu, na stvari možemo primijeniti izraz biće ili reći da su "ono što jest" na više načina, slično kao što na dvije stvari možemo primijeniti izraz čovjek na više načina. Primjerice, za kip Apolona kažemo da je čovjek jer nalikuje čovjeku, a za Sokrata kažemo da je čovjek zato što doista jest takvo i takvo biće. Prema učenju iz Kategorija upravo bi kip Apolona i Sokrat bile homonimne stvari. Ali Aristotel eksplicitno niječe da je u slučaju izraza biće riječ o takvoj homonimiji, odnosno možemo reći da on niječe da su sve postojeće stvari međusobno homonimne (Aristotel, 1924a; Met. IV.2, 1003a34). Kada govorimo o bićima, odnosno o izrazu biće, podrazumijevamo neki odnos s obzirom na jedno $(\pi \rho \grave{\varsigma} \varsigma$ $\tilde{v})$. Naime, za x, y i z na različite načine kažemo da su bića (tj. da postoje ili egzistiraju), ali uvijek u odnosu na nešto jedno (Aristotel, 1924a; Met. IV.2, 1003a33). Hoćemo li tu činjenicu konotirati poput Owena $(1960,169)$ govorom o žarišnom, odnosno fokalnom značenju izraza biće ili poput Vasilisa $(2004,104$ 105) govorom o žarišnoj, odnosno fokalnoj strukturi bića, nije toliko bitno. Ključno je naglasiti da postoji neka primarna uporaba izraza biće, odnosno da postoji neko primarno biće. Takvo nešto nije svojstveno za homonimiju iz Kategorija.

Spomenuto primarno biće Aristotel u Metafizici naziva supstancijom, odnosno primarnu uporabu izraza biti izjednačava s "biti supstancija" (Aristotel, 1924a; Met. IV.2, 1003b16-19). Prema tomu, za stvar x kažemo da je biće zato što je supstancija, za stvar y kažemo da je biće zato što je kvantiteta supstancije, a za 
z kažemo da je biće zato što je kvaliteta supstancija. Jednostavno, za sve se ono za što se može reći da jest (tj. da postoji ili egzistira) kaže da jest s obzirom na supstanciju. U svakom slučaju, takva nas analiza vodi prema Owenovu $(2003,157)$ zaključku kako glagol biti u svojoj egzistencijalnoj uporabi ima mnoštvo nereducibilnih smislova. Slično kao i u analizi prethodnoga odlomka, možemo reći da biće nije neki posebni rod koji se može predicirati, nego postoji nekoliko najopćenitijih rodova na osnovi kojih možemo klasificirati sve postojeće stvari, tj. bića: neka shvaćamo kao neko "ovo" (tj. supstancije), neka kao neko "kakvo nečega", neka kao neko "koliko nečega" i dr. Reći da nešto jest (tj. postoji) pretpostavlja, dakle, mogućnost klasificiranja te stvari kroz dugačak lanac subjektno-predikatnih rečenica u jedan od najviših rodova o kojim ne možemo više ništa predicirati. Dakako, spomenuti najviši rodovi su Aristotelove kategorije. Možemo ilustrirati na primjeru. Za Sokrata tako kažemo da je čovjek, a za čovjeka da je živo biće, da je supstancija. Za svojstvo nekoga zida kažemo da je bijelo, za bijelo kažemo da je boja, za boju pak da je afekcija, a za afekciju da je kvaliteta neke supstancije. Za svojstvo piramide kažemo da je visina, za visinu kažemo da je broj, za broj kažemo da je diskretan, a za diskretne stvari kažemo da su kvantitete neke supstancije i dr. Za Sokrata, bjelinu zida i visinu piramide znamo da su bića na osnovi toga što znamo da su pripadnici kategorije supstancije, kvalitete i kvantitete. Primijetimo da ne samo da je takvo razrješenje postojanja drugačije od jednoznačne quineovske koncepcije egzistencije, nego da su i rezultati primjene takvoga shvaćanja egzistencijalnoga biti drugačiji. Ne možemo reći da imamo tek listu postojećih stvari, nego imamo i neku uređenu hijerarhijsku strukturu gdje su upravo supstancije osnovna i primarna bića, a sva su ostala bića, tzv. nesupstancije, ontološki ovisna o supstancijama. Bića iz kategorije supstancije jednostavno postoje na drugačiji način nego bića iz ostalih kategorija. ${ }^{3}$

K tomu, Aristotel ne želi samo pokazati da je egzistencijalno biti višeznačno. Takav je zaključak prvenstveno interesantan nama koji smo naviknuli na jednoznačno quineovsko shvaćanje egzistencijalnoga biti. Aristotelu je jednako stalo pokazati da glagol biti u svojoj predikativnoj uporabi također ima više značenja. Primjerice, u odnosu na Sokrata predikacije "Sokrat je čovjek", "Sokrat je bijel" i "Sokrat je otrovan" različit su tip predikacija upravo zato što vrsta čovjek te svojstva bijelost i otrovanost postoje na različite načine. Bijelo naime izražava ono što postoji kao kvaliteta nekoga određenoga subjekta, otrovano označava ono što postoji kao stanje nekoga određenoga subjekta, a čovjek označava upravo ono što određuje neki subjekt. Predikativno biti u rečenici "Sokrat je čovjek" je "biti neko ovo", u rečenici "Sokrat je bijel" je "biti neko kakvo nečega", a u rečenici "Sokrat je otrovan" je "biti neko stanje nečega". Drugim riječima, stvari koje postoje na različite načine, kao neko "ovo", kao neko "kakvo nečega", kao neko "koliko nečega", kao neko "stanje nečega" i sl. prediciraju se u različitim

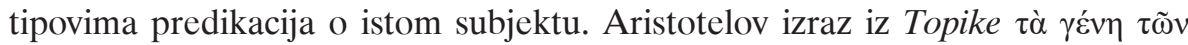

3 Za sličan argument usp. Aristotel 1974; Cat. 5, 2a34-2b6. Za suvremenu teoriju inspiriranu tim redcima usp. Schaffer, 2009. 


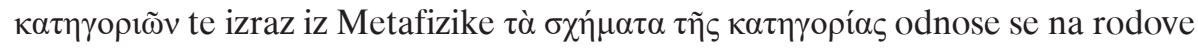
(tipove, sheme, obrasce) predikacija, a ne na rodove (tipove, sheme, obrasce) predikata, odnosno stvari na koje se ti predikati odnose. Sve se naše subjektnopredikatne rečenice mogu svesti upravo na deset osnovnih tipova predikacija kojima se odgovara na neko tzv. kategorijsko pitanje: "Što jest subjekt?”, "Koliki je subjekt?", "Kakav je subjekt?” i dr.

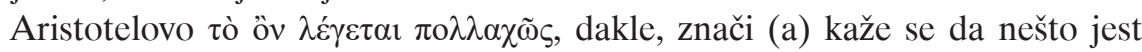
(egzistencijalno) na više načina, kao supstancija, kvaliteta, kvantiteta i dr., ali i (b) kaže se da nešto jest (predikativno) na više načina, "to i to", "takvo i takvo", "toliko i toliko" i dr. Dakako, kao što je primijetio Barnes (2012, 198), hoćemo li neku subjektno-predikatnu rečenicu shvatiti kao točno neku predikaciju iz (b) ovisi o tomu u koju kategoriju iz (a) pripada stvar označena s predikatnim imenom iz neke subjektno-predikatne rečenice koju želimo klasificirati. U konačnici, na osnovi rečenoga možemo zaključiti kako subjektno-predikatna rečenica, tj. rečenica u kojoj se predicira neko biće, objelodanjuje neki odsječak izvanjezične i izvanmentalne stvarnosti, uvjetno rečeno, nužnu činjenicu da je neka pojedinačnost pripadnik neke vrste, te kontingentu činjenicu da je neka (određena) pojedinačnost okvalificirana nekim akcidentom (usp. Aristotel, 1924a; Met. VI.4, 1027b18-23; IV.7, 1011b26-27; V.29, 1024b26-28; 1924b; VI.4, 1027b17-1028a6; Rijk, 2002; Kahn, 2009; Hestir, 2013). ${ }^{4}$

\section{Izazov nepostojećega}

U svojem djelu Sustav logike Mill $(2009,96)$ eksplicitno povlači razliku između predikativnoga i egzistencijalnoga biti, odnosno tvrdi kako nije moguće iz rečenice forme "S je P" izvesti rečenicu "S jest" (tj. postoji ili egzistira). Prema Millu glagol biti u subjektno-predikatnim rečenicama ima tek sintaktičku službu kopule pomoću koje se izražava afirmacija nekoga svojstva subjektu, ali takvo biti ni na koji način ne izražava egzistenciju subjekta. Aristotel se može složiti s Millom da sâmo biti u tročlanim rečenicama ne označava nikakvo svojstvo subjekta (usp. Aristotel, 1949; Apr. I.1, 24b16-18 i 3, 16b22-25), ali za Aristotela, kako smo vidjeli, svaka subjektno-predikatna afirmativna rečenica objelodanjuje neki splet kategorija, odnosno izražava da neki odsječak izvanjezične i izvanmentalne zbilje jest. Dakako, samim time svaka nas subjektno-predikatna rečenica u suvremenom smislu obvezuju na postojanje stvari koja odgovara subjektnom terminu. Mill, međutim, nudi vrlo uvjerljiv primjer zašto bi takvo razmišljanje moglo biti pogrješno.

4 Aristotel razlikuje biće uzeto u strogom smislu (naše kopulativno i egzistencijalno biti), veridičko biti (naša tvrdnja kako predikacija objelodanjuje da neka činjenica jest), ali i biće u izvedenom smislu te potencijalno i aktualno biće (Aristotel, 1924a; Met. V.7 1017a7-1017b9). Pretposljednja uporaba donekle je usporediva s raspravom u podpoglavlju 2.1., a posljednja donekle s raspravom u podpoglavlju 2.2, a dobrim je dijelom u podlozi srednjovjekovnoga razlikovanja između tzv. actualia, possibilia i impossibilia (usp. Novotný, 2012). 
»Da uvođenje je kao kopule ne uključuje nužno afirmaciju egzistencije, čini se očitim iz slučajeva rečenica poput "Kentaur je fikcija pjesnika", gdje nije moguće implicirati da Kentaur postoji jer sama rečenica izričito izražava da ta stvar nema realnu egzistenciju« (Mill, 2009, 96).

Rečenica "Kentaur je fikcija pjesnika" i njoj slične poput "Kentaur je izmišljen" i "Kentaur je plod mašte" imaju gramatičku strukturu afirmativne subjektno-predikatne rečenice u kojoj je izražen neki relevantan smisao glagola biti. Prema tomu, takve bi nas rečenice trebale obvezivati da imenom Kentaur označavamo neko biće, odnosno da postoji biće koje je fikcija pjesnika, izmišljeno biće i biće koje je plod mašte. Ali ne podrazumijevamo li mi da reći da je nešto fikcija i sl. znači upravo zanijekati tomu nečemu ontološki status izvanjezičnoga i izvanmentalnoga bića? Štoviše, Aristotel sugerira da tzv. prazna imena poput Kentaur i jarcojelen označavaju nešto, iako njihov significatum ne odgovara nekomu jedinstvenomu biću (usp. Aristotel, 1974; De Int. 1, 16a16-17; Aristotel, 1949; Apo. II.7, 92b6-7). Međutim, ako primijenimo dosadašnju interpretaciju, čini se da svaka afirmativna predikacija s praznim subjektnim terminom mora obvezivati na postojanje nekoga određenoga subjekta. Drugim riječima, Aristotelu prijeti inačica suvremenoga problema fikcijskoga diskursa. Srećom, Aristotel je i te kako svjestan opasnosti rečenica poput "Kentaur je izmišljen" te na četiri mjesta upućuje na moguće rješenje.

»Kao što je Homer nešto, primjerice pjesnik, je li tada Homer također jest ili

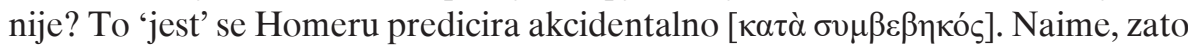

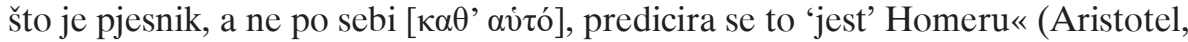
1974; De Int. 11, 21a25-28).

»Za nebiće [ $\mu$ ò óv], s obzirom na to da je pomislivo, nije zato istinito reći da je neko biće [őv $\tau$ l]. Misao naime o njemu nije da jest, nego da nije « (Aristotel, 1974; De Int. 11, 21a33-34).

»Ako je nebiće pomislivo, onda nebiće jest. Ali nije naime isto 'biti nešto'

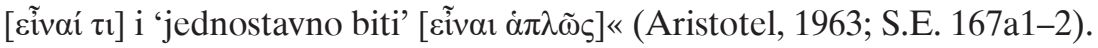

»'Biti nešto' [Eĩvaí $\tau 1$ ] i 'biti' [Eĩval] nije isto - nije naime tako da time što

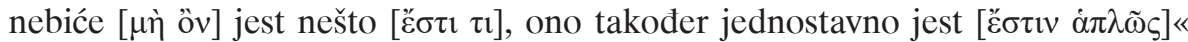
(Aristotel, 1963; S.E. 180a36-38).

Suočeni s navedenim redcima brzopleto bismo mogli konstatirati da Aristotel razmišlja vrlo blisko Millu. U tom slučaju moramo odustati od tvrdnje da je glagol biti na neki način unificiran kao predikativno i egzistencijalno biti, odnosno od tvrdnje da predikacija nosi sa sobom egzistencijalnu obvezu. Ipak, Aristotel ne razmišlja poput Milla. Njegovo se rješenje problema nepostojećega krije u činjenici da rečenica poput "Kentaur je fikcija pjesnika" nije uopće subjektnopredikatna rečenica kojom se objelodanjuje neki splet kategorija, a samim time takva rečenica ne objelodanjuje nikakav odsječak izvanjezične i izvanmentalne stvarnosti. 


\subsection{Kompleksni predikati}

Citirani se odlomci pojavljuju u kontekstu Aristotelove rasprave o mogućnosti rastavljanja kompleksnoga predikata u $O$ tumačenju, odnosno u kontekstu rasprave o jednoj logičkoj pogrješki u Sofističkim opovrgavanjima. Pogledajmo dva para rečenica.
(A) Sokrat je bijeli govornik.
(C) Sokrat je dobar govornik.
(B) Sokrat je bijel.
(D) Sokrat je dobar.

Iz (A) slijedi (B), ali iz (C) ne slijedi (D). Iz (C) ne slijedi (D) zato što se dobar u (C) ne predicira o Sokratu u apsolutnom smislu, nego s obzirom na njegovo govorničko umijeće. Dobar u (C) zapravo ne odgovara na pitanje "Kakav je Sokrat?", nego na pitanje "Kakav je Sokrat s obzirom na govorničko umijeće?" U (A) bijel se odnosi u apsolutnom smislu na Sokrata, pa možemo zaključiti i na (B). Izvođenje (D) iz (C) tradicionalno se naziva pogrješka secundum quid. U kontekstu rasprave o kompleksnim predikatima zaključci su isti. (D) ne slijedi iz (C), ali (B) slijedi iz (A). Naime, neka se kompleksna predikacija poput (A) i (C) može rastaviti na jednostavne predikacije ako i samo ako se dijelovi kompleksnoga predikata prediciraju po sebi, a ne u akcidentalnom smislu, tj. s obzirom na nešto drugo. Dakako, bijel u (A) predicira se po sebi o Sokratu, neovisno o njegovu govorničkom umijeću, a dobar u (C) ne predicira se Sokratu po sebi, nego upravo s obzirom na njegovo govorničko umijeće. ${ }^{5}$

Aristotelova poanta u odlomku s Homerom ne tiče se razlikovanja predikativne i egzistencijalne rečenice i neopravdanosti zaključivanja na egzistencijalnu rečenicu iz predikativne. Aristotelova poanta tiče se činjenice da "Homer jest" nije uopće jednostavna predikacija, a time rečenica "Homer je pjesnik" nije kompleksna predikacija. Naime, rečenica "Homer je pjesnik" jednostavna je, paradigmatska predikacija. Izraz je, kako Aristotel kaže u prvom odlomku, ne

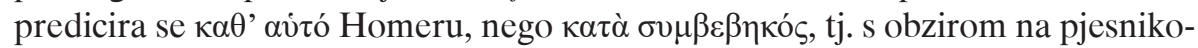
vanje, slično kao što se dobar u (C) ne predicira Sokratu po sebi, nego s obzirom na govorničko umijeće. Rečenica "Homer jest" (tj. postoji ili egzistira) prema tomu nije jednostavna predikacija jer izrazi jest, biće i postojeće ne označavaju neko specifično svojstvo, odnosno pripadnika kategorijske sheme, koji bi se mogao po sebi predicirati subjektu u nekoj od shema predikacija, a samim time se rečenica "Homer jest" ne može izlučiti iz "Homer je pjesnik" sukladno pravilu o rastavljanju kompleksnoga predikata. ${ }^{6}$

\subsection{Gramatička prediciranja bez ontološke obveze}

Za sada smo pokazali da Aristotel ne negira u primjeru s Homerom dosadašnje nalaze, a na osnovi drugoga odlomka možemo doći do sličnih zaključaka, s time da nam je tu naznačeno kako postupiti s rečenicama poput "Kentaur je

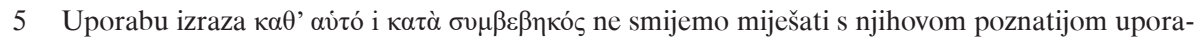
bom kao izraza koji označavaju pripisivanje esencijalnoga i akcidentalnoga svojstva.

6 Za slična rješenja navedenoga odlomka usp. Carson, 2000; Wedin, 1978. Za različita rješenja usp. Rijk, 2002; Kahn, 2009. 
izmišljen”. Aristotel tvrdi da iz činjenice da nešto jest pomislivo ili, moderno rečeno, da nešto jest intencionalni objekt ne slijedi da je riječ o nekom biću. Primjerice, iz rečenice "Himera je pomisliva" ne slijedi da je Himera neko biće. Zaključak je poprilično intuitivan jer predmeti naših misli zasigurno ne moraju postojati u izvanjezičnoj i izvanmentalnoj stvarnosti, ali Aristotel želi reći nešto puno informativnije. Ključno je primijetiti da Aristotel ne kaže da iz činjenice da je nešto pomislivo ne slijedi da je riječ o biću, tj. postojećoj stvari, nego da ne slijedi da je riječ o nekom biću (őv $\tau$ )). Izraz neko biće ovdje implicira upravo onu određenost o kojoj smo govorili u podpoglavlju 1.2. - smještanje bića unutar kategorijske diobe postojećih stvari. ${ }^{7}$ Primjerice, možemo reći da je Zvonko biće, ali kada kažemo da je Zvonko perzijski mačak, tada smo specificirali o kojem je određenom biću riječ. Također, ako kažemo nekomu "Tirkiz je biće", naš sugovornik još ne zna o kojem biću je riječ, niti čak može znati da se izraz tirkiz uopće i odnosi na postojeću stvar. Ali ako kažemo “Tirkiz je boja”, moj sugovornik može znati da govorimo o nekom postojećem biću te o biću koje postoji kao kvaliteta neke supstancije. Aristotel nam u drugom odlomku želi samo reći da pomisliva bića nisu nužno i bića iz kategorijske diobe, tj. tipične postojeće stvari u njegovoj ontologiji.

Takav se zaključak može iščitati još izravnije iz trećega i četvrtoga odlomka, ali se opet moramo čuvati brzopletosti slično kao u odlomku o Homeru. Naime, kada Aristotel izričito razlikuje "jednostavno biti" (عĩvol $\dot{\alpha} \pi \lambda \tilde{\omega} \varsigma)$ i "biti nešto" (E⿱艹vaí $\tau$ ), on ne opovrgava svoju analizu glagola biti kao glagola koji nema apsolutno značenje, nego nekoliko različitih. Aristotel nam skreće pažnju na to da u jeziku postoje rečenice s takvim predikatnim sintagmama na osnovi kojih ne možemo reći da postoji izvanjezično i izvanmentalno biće u pozadini subjektnoga termina. Razlog zašto je tomu tako vrlo je jednostavan: nisu sve rečenice gramatičke strukture "S je P" ujedno subjektno-predikatne rečenice u logičko-ontološkom smislu kojima se cilja na objelodanjivanje spleta kategorija. Nešto preciznije, postoje takve predikatne sintagme, primjerice neko "x je F" u kojoj izraz biti ne označava ni jedan od načina prediciranja iz Kategorija i Topike, odnosno nije svako "x je F" znak za "biti neko ovo", "biti neko kakvo neke supstancije", "biti neko koliko neke supstancije" i sl.

Na osnovi čega znamo da je biti u nekom fragmentu "x je F" doista znak jedne od shema predikacija? Odgovor se krije u izrazu F. Naime, ako F označava neko biće iz kategorijske razdiobe, onda i fragment "x je F" označava jednu od shema predikacija kojom se cilja na objelodanjivanje spleta kategorija. Primjerice, ako umjesto F stoji čovjek ili bijel u fragmentu "x je F", za bilo koji subjektni termin generirana je subjektno-predikatna rečenica kojom se objelodanjuje što subjekt jest i kakav subjekt jest, a samim time slijedi da subjektni izraz mora označavati neko biće. S druge strane, ako umjesto F stoji pomisliv, glagol biti u fragmentu "x je pomisliv" ne izražava neku od shema predikacija jer, kako smo prije rekli, predmeti naših misli ne moraju postojati u izvanjezičnoj i izvanmentalnoj zbilji. 
Naime, izrazom pomisliv ne odgovaramo ni na jedno kategorijsko pitanje jer iza izraza pomisliv ni ne stoji u pozadini pripadnik kategorije supstancije i kvalitete, kao što stoji u pozadini izraza čovjek i bijel. Sukladno rečenomu, "Sokrat je pomisliv" nije uoće predikacija koja nas obvezuje da postoji jedno pomislivo biće imena Sokrat. I nama najvažnije, "Himera je pomisliva" ne obvezuje nas da postoje takva pomisliva bića koja su Himere, odnosno rečenica "Himera je pomisliva" ne obvezuje nas da neki odsječak izvanmentalne stvarnosti jest, kao što nas obvezuje bilo koja tipična predikacija. Takvom rečenicom tvrdimo samo da je Himera smještena u sferu mentalnoga, a ne u sferu izvanmentalnoga kao predmet koji može biti određen kao pripadnik neke vrste ili kao predmet koji je kvalificiran nekom kvalitetom, kvantitetom i sl.

Aristotel se je tu više-manje zaustavio, vjerojatno jer je on bio prvenstveno zainteresiran za bića u strogom smislu, tj. za bića u izvajezičnoj i izvanmentalnoj stvarnosti, ali srednjovjekovni filozofi odlaze korak dalje. Glagol biti u rečenicama poput "Himera je pomisliva" — koje dakle nisu predikacije su strogom smislu — naziva se esse intentionale, a za stvari koji imaju takav bitak kaže se da su entia rationis. Iako srednjovjekovni filozofi nemaju ni blizu jedinstveno shvaćanje bića razuma, ${ }^{8}$ suvremena ficta, poput Sherlocka Holmesa i Ahileja, ili razna impossibilia, poput zlatne planine, svakako su primjeri bića razuma. Dakako, osnovno je određenje bića razuma to da ona nisu izvan uma (extra mentem), nego u umu (in mente), a samim time posve su prihvatljive, bez straha od paradoksa, rečenice poput "Himera je pomisliva" jer se takvim rečenicama ništa ne postavlja u stvarnost (nihil in re ponat).

U nedostatku prostora, recimo samo to da je upravo problem fikcijskoga diskursa, ocrtan na početku rada, potaknuo mnoge suvremene filozofe na odstupanja od tipične quineovske koncepcije egzistencije i predikacije - i to prema tradicionalnijim koncepcijama, gdje prepoznajemo bića razuma, intencionalne objekte, različite načine postojanja, različite tipove gramatičkih subjektno-predikatnih rečenica, od kojih neke nisu predikacije u strogom logičko-ontološkom smislu i sl. (usp. Crane, 2012; Reicher, 2019).

\section{Zaključak}

Problem nepostojećega, kako ga je formulirao Quine, ne predstavlja izazov za Aristotelovu subjektno-predikatnu analizu. Za rečenicu poput "Himera ne postoji” Aristotel nikada ne bi rekao da je subjektno-predikatna rečenica kojom se izdvaja neki predmet o kojem ne važi neki predikat. Sâm izraz biti i njemu srodni izrazi jednostavno nisu predikatni termini. Aristotel se, doduše unutar svojega konceptualnoga okvira, posvećuje problemu nepostojećega. Polazeći od činjenice da subjektno-predikatne afirmativne rečenice objelodanjuju da neki odsječak izvanjezične i izvanmentalne stvarnosti jest, rečenica poput "Himera je 
pomisliva" mogla bi predstavljati izazov. Aristotel, međutim, pokazuje da ni ta rečenica nije tipična subjektno-predikatna rečenica. Izrazom pomisliv ne moramo označavati bića iza kategorijske diobe postojećih stvari, a samim time rečenicom "Himera je pomisliva" ne odgovaramo ni na jedno tzv. kategorijsko pitanje: "Što jest?", "Koliko jest?" "Kakvo jest?" i sl. Srednjovjekovni, ali i suvremeni filozofi, naslanjajući se na takvo rješenje, predlažu raznolika rješenja problema povezanih s nepostojećim.

\section{Literatura}

Aristotel (1924a). Aristotle's Metaphysics: Volumen 1. Oxford: Oxford University Press. Aristotel (1924b). Aristotle's Metaphysics: Volumen 2. Oxford: Oxford University Press. Aristotel (1949). Aristotle's Prior and Posterior Analytics. Oxford: Oxford University Press. Aristotel (1963). Aristotelis Topica et Sophistici Elenchi. Oxford: Oxford University Press. Aristotel (1974). Aristotelis Categoriae et liber De Interpetatione. Oxford: Oxford University Press.

Barnes, Jonathan (2012). Aristotle's Categories and Aristotle's categories. U: Maddalena Bonelli (ur.), Logical Matters: Essays in Ancient Philosophy II (str. 187-256). Oxford: Oxford University Press.

Berti, Enrico (2009). Aporiai 6-7. U: Michel Crubellier i André Laks (ur.), Aristotle: Metaphysics Beta (str. 105-133). Oxford: Oxford University Press.

Carson, Scott (2000). Aristotle on Existential Import and Nonreferring Subjects. Synthese, $124(3), 343-360$.

Crane, Tim (2012). What is the problem of non-existence? Philosophia, 40, 417-434.

Frege, Gotlob (1960). Die Grundgesetze der Arithmetik. U: Peter Geach i Max Black (ur.), Translations from the Philosophical Writings of Gottlob Frege (str. 137-158). Oxford: Blackwell.

Hestir, Blake (2013). Aristotle's Conception of Truth: An Alternative View. Journal of the History of Philosophy, 51(2), 193-222.

Inwagen, Peter van (2009). Being, Existence, and Ontological Commitment. U: David Chalmers, David Manley i Ryan Wasserman (ur.), Metametaphysics: New Essays on the Foundations of Ontology (str. 472-506). Oxford: Oxford University Press.

Kahn, Charles (2009). A Return to the Theory of the Verb Be and the Concept of Being. U: Charles Kahn (ur.), Essays on Being (str. 109-142). Oxford: Oxford University Press.

Loux, Michael (2009). Aristotle on universals. U: Georgios Anagnostopoulos (ur.), $A$ Companion to Aristotle (str. 186-196). Oxford: Blackwell.

Mill, S. John (2009). A System Of Logic, Ratiocinative And Inductive. New York: Harper \& Brothers.

Novotný, D. Daniel (2012). Scholastic Debates about Beings of Reason and Contemporary Analytical Metaphysics. U: Lukáš Novák i Daniel, Daniel Novotný, Prokop Sousedík i David Svoboda (ur.), Metaphysics:Aristotelian, Scholastic, Analytic (str. 25-40). Heusenstamm: Ontos-Verlag.

Owen, E. L. Gwilym (1960). Logic and metaphysics in some earlier works of Aristotle. U: Ingemar Düring i Gwilym E. L. Owen (ur.), Aristotle and Plato in the Mid-Fourth Century (str. 163-190). Göteborg: Almquist \& Wiksell.

Owen, E. L. Gwilym (2003). Aristotel o zamkama ontologije. U: Pavel Gregorić i Filip Grgić (ur.), Aristotelova Metafizika (str. 149-173). Zagreb: KruZak. 
Quine, Willard van Orman (1980). From a Logical Point of View. New York: Harper. Quine, Willard van Orman (2011). Ontološka relativnost i drugi ogledi. Zagreb: KruZak. Reicher, Maria (2019). Nonexistent Objects. U: Stanford Encyclopedia of Philosophy. https://plato.stanford.edu/entries/nonexistent-objects/ (27.11.2020.)

Rijk, Lambertus Marie de (2002). Aristotle: Semantics And Ontology I. Leiden: Brill.

Russell, Bertrand (2010). The Philosophy of Logical Atomism. New York: Routledge.

Schaffer, Jonathan (2009). On What Grounds What. U: David Chalmers, David Manley i Ryan Wasserman (ur.), Metametaphysics: New Essays on the Foundations of Ontology (str. 347-383). Oxford: Oxford University Press.

Talanga, Josip (ur.) (1989). Aristotel: O tumačenju. Zagreb: Latina et Graeca.

Vasilis, Politis (2004). Aristotle and the Metaphysics. London: Routledge.

Wedin, V. Michael (1978). Aristotle on the Existential Import of Singular Sentences. Phronesis, 23, 179-196.

The Puzzle of Non-Existence and Aristotle's Subject-Predicate Analysis

\section{Igor Martinjak*}

\section{Summary}

According to the well-known argument, a traditional conception of existence and predication leads to the infamous paradox of non-existence. For instance, the sentence 'Pegasus does not exist' commits us to accept that there is something that does not exist. The easy way out is to analyze existence as a second-order concept expressing that there is at least one instance of some first-order concept. In this article, I argue that the traditional conception of existence and predication does not lead to the paradox of non-existence. Negative existentials simply are not subject-predicate sentences that select existing beings only to deny them the property of existence. Aristotle's insistence that being is not a genus, i.e. that being is not a predicate of some subject, is pivotal. Furthermore, Aristotle does not have a uniform conception of existence and predication. According to Aristotle, to be is to be an item in the categorical scheme, and consequently, every predication of some being should be analyzable as one of the most general types of predication according to the categorical scheme. However, in the conceptual framework of Aristotle's philosophy, there arises a different problem of non-existence. For instance, 'Pegasus is thought-about' might commits us to accept that Pegasus is a being of some kind. I reconstruct Aristotle's solution as being satisfactory in the light of his understanding of predication and existence. Moreover, I suggest that a similar puzzle leads many contemporary philosophers to an abandonment of the Quinean concept of existence and predication in favour of a more traditional approach.

Key words: existence; non-existent being; predication; ways of being

* Igor Martinjak, Ph.D., Faculty of Philosophy and Religious Studies, University of Zagreb. Address: Jordanovac 110, 10000 Zagreb, Croatia. E-mail: igor.martinjak@yahoo.com 